\title{
The Imagination: A Path to Personal and Planetary Individuation
}

\author{
Ciúin Doherty, M.A.*
}

Pacifica Graduate Institute

\begin{abstract}
This paper draws on Jungian psychology, neuroscience, and cosmology to explore the role of the imagination in facilitating individuation at personal and planetary levels. It proposes that the imaginative faculties are essential to overcoming not only the divisions within an individual's psyche but also the alienating sense of disconnection that much of humanity currently experiences from the planet, a severance that paves the way for the continued destruction of the biosphere. If we can truly acknowledge that humankind was birthed by Earth, that we are in fact Earth in human form, then through us the planet acquires the capacity to imagine radically new futures for itself. In this symbiotic process, we too are gifted the possibility of living into our potential as the very heart and mind of our sacred planet.
\end{abstract}

\section{Introduction}

To be human is to be an extension of that original energy that emerged mysteriously at the beginning of time. This energy moving through me was just recently the sun, and the sun itself gets its energy from the fusion process of atoms, these atoms got their energy from near the birth of the universe, so coursing through you and me now is the energy of the birth of the universe. (Swimme, 2007, 56:00)

No wonder the currents of the imagination can, at times, feel wild, spontaneous, otherworldly. They are the reverberations of exploding stars coursing through our veins, calling us to become part of the creative impulse of the universe itself, beseeching us to give birth to that which is uniquely ours, demanding that we play our part in the evolution of the cosmos. Are we really going to ignore these primeval streams of energy for fear they may upset our orderly, predictable lives? If we are an extension of this ingenious universe, do we not have a duty to notice what is moving through us, to support that

*ciuindoherty@gmail.com 
which is attempting to be born through us?

\section{Imagination and the Cosmos}

Archetypal psychologist Hillman and his coauthor Ventura called for a more daring psychology: "I want theories that blow the mind. ... The value of a psychological theory lies in its capacity to open the mind, take the top of your head off like a good poem or a voice in a song" (Hillman \& Ventura, 1992, p. 69). This paper is inspired by Hillman and Ventura's rallying cry and hopes to play some part in bringing forth ideas that stir the heart, thrill and terrify the intellect. It builds upon the recognition by the founder of analytical psychology Jung (1946/1960) and post-Jungians such as Shulman (1997) and Rowland (2012) that the imagination is an extension of the primordial creativity of the universe. It proposes that our listening to and dialoguing with this outpouring of original energy is tantamount to engaging with the generative powers of the emergent macrocosm itself.

When we see the human being as both an individual and a mode of the universe (Berry, 1988, p. 16) it has profound implications for the psychotherapeutic dialogue. Through this dual focus lens our lives can be viewed both as our own projects and as ways in which the whole finds ever greater self-expression. On an experiential level, the individual's journey becomes that of the cosmos. Such radical shifts in perspective may facilitate not only our personal movement toward wholeness but also the very individuation of planet Earth.

While much has been written on the imagination from Jungian points of view (Chodorow, 1997; Johnson, 1986), we are only beginning to ask what modern science, particularly neuroscience (Badenoch, 2008; McGilchrist, 2011, 2012; Marks-Tarlow, 2012) and cosmology (Berry, 1988, 1999; Swimme, 2001, 2007, 2011), might have to contribute to this field. It is time to harness the staggering insights around the origins of the universe and the functioning of the brain to illuminate this most startling aspect of what it is to be human.

\section{Active Imagination and Individuation}

There are many different ways to conceive of the imagination, but Jungian analyst Johnson (1986) broke it down as follows: "The root of the word imagination is the latin word imago, meaning 'image'; the imagination is the image-forming faculty of the

mind" (p. 22). For clinical psychologist Marks-Tarlow (2012), "The human imagination represents the pinnacle of evolution. Through the inner channels of the imagination we 
can see through the eyes of others, travel back to the past, anticipate future circumstances, visit imaginary places and create impossible worlds" (p. 149).

Jung's method of deeply engaging these imaginal realms he termed active imagination. This process involves loosening the rigidity of the ego and allowing the figures of the unconscious mind to surface (Jung, 1969b, p. 537 [CW 11, para. 875]). First, an image is chosen, be it from a dream, fantasy, or some other part of one's inner world, and then it is given a special type of attention. In German, the word Betrachten describes this way of looking at something whereby one impregnates it with one's attention (Chodorow, 1997, p. 7). "One concentrates upon it, and then finds that one has great difficulty in keeping the thing quiet, it gets restless, it shifts, something is added, or it multiplies itself; one fills it with living power and it becomes pregnant" (Jung, 1997, p. 661). It is this "conscious participation in the imaginal event that transforms it from mere passive fantasy to active imagination.... When we experience the images, we also directly experience the inner parts of ourselves that are clothed in the images" (Johnson, 1986, pp. 24-25). These inner parts could be imagined as personality fragments or subpersonalities, each with their own energy and a certain level of consciousness and purpose (Stein, 2013, pp. 44-50).

Individuation is the term that Jung (1969a) used to describe the process of integrating the components of the psyche into a well-functioning whole: "I have called this wholeness that transcends consciousness the 'Self.' The goal of the individuation process is the synthesis of the Self" (p. 164 [CW 9i, para. 278]). For Johnson (1986), individuation is "the lifelong process of becoming the complete human being we were born to be. Individuation is waking up to our total selves" (p. 11).

If, at the individual level, this integrative process is about seeking to become conscious of our total selves, then individuation at the planetary scale could be imagined as our waking up to our inherent interconnectivity with, dependence upon, and responsibility toward Earth and all its species. Such a journey would involve overcoming the deeply embedded Western illusion of separateness of self (Watts, 1989, p. 80), recognizing that we are one part of a greater whole encompassing not only this planet but the entire universe beyond. It would require our acknowledgment that humanity was birthed by the earth; that each person, in a very real sense, is an outgrowth or extension of the planet itself. Therefore, as we individuate, waking up to all of who we are, including our greater identity as Earth itself, we simultaneously allow the planet to individuate. As humanity develops ever-greater self-awareness, Earth has the possibility of becoming conscious of itself through the human (Berry, 1988; Teilhard de Chardin, 1955). In this process, not only does the planet gain the capacity for self-reflexive 
awareness, but humanity provides the space through which Earth's imagination gets to flare forth (Swimme, 1997, 12:00). Via the creativity of the human psyche, Earth acquires the potential to envisage radically new futures for itself. In our time of impending ecological catastrophe this type of planetary imagination will be absolutely indispensable.

\section{The Balance of Power in the Brain}

Shortly before his death the great mythologist Campbell (1988) stated, "The only myth that is going to be worth thinking about in the immediate future is one that is talking about the planet, not the city, not these people, but the planet, and everybody on it" ( $p$. 41). For cultural historian Berry (1988), our recent scientific discovery that every person, species, and element of the cosmos emerged out of a point smaller than a grain of sand in the Big Bang 13.8 billion years ago, "when recounted as a story, takes on the role formerly fulfilled by the mystic stories of creation. . . . Science has given us a new revelatory experience. It is now giving us a new intimacy with the earth" (p. 15, 18).

However, if we are truly to live into a renewed sense of intimacy with the planet we must pay attention to what psychiatrist McGilchrist (2012) described as the balance of power between the two hemispheres of the brain (pp. 428-462). Although the popularized idea that the left brain handles logic while the right facilitates creativity is greatly oversimplified, since in fact both sides are profoundly involved in each function, there are, nonetheless, very real differences in the perspectives on reality offered by the two hemispheres (McGilchrist, 2011, 3:00).

To show how the different hemispheric worldviews evolved, McGilchrist (2011) cited the example of a bird feeding on seeds scattered among grit and pebbles. In order to locate the seed, the bird uses the left hemisphere's very narrowly focused, precise type of attention, one that knows in advance what it is looking for. Meanwhile, the right side employs precisely the opposite type of attention, seeking the broadest possible view as it scans the horizon for potential predators, friends, or whatever else is going on, with no presuppositions as to what it may find (5:00). Thus, the right brain has the capacity to take in the whole, while the left, through its lens of division and separation, sees only an agglomeration of parts (McGilchrist, 2012, p. 55). This perspective makes the left hemisphere incredibly skilled when it comes to manipulating the world, but it also divorces us from the underlying unity of the universe, for the left side cannot see the whole: it is literally incapable of perceiving the big picture. In addition, the left codes for the nonliving, so an overreliance on this hemisphere transforms nature from a vibrant, 
pulsing, intelligent whole into a collection of inanimate objects or resources available for human consumption (p. 57).

Due to the right brain's openness to the interconnectedness of things, it is the mediator of empathetic identification (McGilchrist, 2012, p. 57). In the absence of this hemisphere, "social intercourse is conducted with a blanket disregard to the feelings, wishes, needs and expectations of others" (Schutz, as cited in McGilchrist, 2012, p. 58). The right side is more intimately connected with the limbic system, which is involved in the experience of emotions of all kinds (pp. 57-58). It is also the center of the embodied self and is responsible for "our sense of the body as something we 'live' . . the phase of intersection between our selves and the world at large" (p. 67). For the left hemisphere, on the other hand, the body is something from which we are relatively detached-it is simply another thing in the world; it is devitalized, a mere assemblage of parts (p. 67).

McGilchrist (2012) argued that we in the West live in a left-shifted society, one that favors the simplified, explicit, decontextualized take on the world offered by the left brain (p. 434). If we are to have any hope of stepping into a mutually enhancing relationship with the entire Earth community we must reengage the right hemisphere and its capacity to perceive the whole, to feel deeply, and to empathize, providing us with a vision of the world that is alive, sentient, interconnected, and available for profound communion and relationship (McGilchrist, 2011, 7:00).

\section{The Journey}

The world is always larger, more intense, and stranger than our best thought will ever reach. And that's the mystery of poetry, you know; poetry tries to draw alongside the mystery as it's emerging and somehow bring it into presence and into birth. (O'Donohue, 2015, 15:00)

Dreams and the imagination, like the world itself, often appear so intense and strange that, feeling overwhelmed, we may be inclined to turn away in confusion. However, I will follow the poets' lead in attempting to draw alongside their enigmatic nature, giving them the space to speak in their own native tongue. Through this process of listening into the mystery I hope to explore the following themes: How might the imagination facilitate individuation at personal and planetary levels? And in what ways could our imaginative faculties play a critical role in overcoming not only the divisions within our individual psyches but also our often alienating sense of separation from the earth? These are crucial lines of inquiry because it seems that in our left-hemispheredominated Western world we are facing a crippling poverty of imagination with regard 
to our individual identities and our role in the cosmos.

In this section, Jung's method of active imagination will be employed in order to investigate a number of my own dream images. Thereafter, I will explore whether this dialoguing with the unconscious may facilitate individuation through two key processes: First, via its potential to integrate dissociated neural nets within the brain; and second as an imaginal version of psychologist Levine's (1997) method of somatic experiencing (p. 152). In addition, the right-hemisphere perspective necessitated by active imagination will be analyzed with particular attention paid to the implications of seeing oneself, others, and the world through this holistic lens. Lastly, the potential impact of these processes on the ways in which we imagine humanity and our role here on Earth will be drawn out.

\section{The Great Escape}

The first imaginal journey to be investigated centers on the dream image of a tiger. When I was a child, the tiger was my favorite animal; its stripes were scrawled all over the margins of my school books, and I was frequently visited by this magnificent creature in my dreams. I loved its ferocity, beauty, and strength. However, as I grew up my old companion gradually disappeared into the mists of time. Having laid dormant for 30 years the tiger erupted once more in my dream life while I was researching topics for this paper.

Intrigued by its sudden reappearance, I decided to invite the powerful visitor into conversation with my waking psyche while taking a series of yoga classes. Held in this meditative, embodied, right brain space I found myself transported back to a difficult childhood memory. Once again, I was alone on the deck of a huge ferry, waving to the distant figure of my mother on the dock below. We were to be separated for the duration of the school term, and as was the pattern at each of these farewells, my heart was breaking anew. Yet, in this active imagination the all-too-familiar story began to shift. Rather than sailing away in a state of despair, watching my mother recede further and further into the distance, I noticed a new figure approaching. It was the tiger from my dream. Huge and majestic, he invited me to jump onto his back. Straddling the fearsome beast, my fingers clutching his thick coat, I held on with amazement as we bounded back down the gangplank, leaping over the many officials trying to block our progress. With

one final spring the tiger vaulted the fence and set me down on the dock, directly into the arms of my mother. 


\section{Reimagining the Story}

The particularly healing element of this imaginal journey is that, in a sense, it rewrote the story of a painful, recurring episode from my childhood. Through joining with the tiger, I shifted from a state of incapacitation into a sense of being able to take decisive actions to determine my fate. As Levine (1997) showed, overwhelming experiences leave long-lasting scars when we are unable to act on our body's fight-orflight response by kicking, punching, or fleeing the perceived danger (pp. 95-97). In these cases, the brain continues to excrete stress chemicals long after the threat has passed (p. 150). On the other hand, if the body is allowed to exercise its natural selfdefense system, major ordeals can be survived without long-lasting effects.

My experience is that during active imagination the psyche can guide us to those dissociated neural nets holding memories of times when we were powerless to fight or flee from painful events. However, rather than simply reexperiencing these split off memories in their original overwhelming form, the imaginative, embodied mind can, seemingly of its own volition, rewrite the ending, provided we keep the nervous system in a regulated state. This imaginal process allows us to emerge in a stronger position, be it through successfully fighting, fleeing, or as in my case, calling in the assistance of a powerful other.

Herein lies the wisdom of the psyche - it knows what to do if we can provide it with the right healing space. When we take a cosmological perspective, is this really any wonder? After all, as Berry and mathematical cosmologist Swimme (1992) argued, we are part of an astonishingly intelligent universe that emerges according to its own selforganizing principles, producing ever-greater variety and intensity in its modes of psychic expression (p. 336). The incredible fact of the matter is that "if you let hydrogen gas alone for 13 billion years it will become giraffes, rose bushes and human beings" (Swimme, qtd. in Fox, 2004, p. 40). Therefore, does it not make sense that our unconscious, our dreams and our imagination, all of which emerged, like everything else in the universe, from a "single multiform energetic unfolding of matter, mind, intelligence and life" (Swimme, 2001, p. 28) might have their own type of innate brilliance?

Interestingly, our dreams and imaginative faculties appear to have lessons to share on the planetary scale as well as at the individual level. While the tiger image allowed me to reunite with my personal mother, from an archetypal perspective it may also have been pointing toward our collective need for reconnection with Mother Earth. The little boy did not want to sail away from his primary source of nurturance; he was simply 
caught in a family system that gave him little other choice. The same seems to be true on a global scale; I don't think that anyone consciously desires the destruction of our exquisite planet, yet we are caught in a global economic system that propels us along just such a cataclysmic path. In the dream, it was the intervention of the tiger, an animal long associated with powerful feminine energy (Hillman, 1997, p. 61) that allowed a painful story of alienation to become a tale of reunion. My sense is that it will take a parallel process of reconnection with the feminine on a global scale to facilitate our transition to a life-enhancing form of humanity.

\section{The Sidelining of the Imagination}

If active imagination has the capacity to facilitate deep healing experiences on a personal level and to inspire reflections upon our collective relationship with Earth, why does it remain a relatively fringe pursuit within psychology as a whole? My sense is that in a left-hemisphere-dominated world, it is feared for its unpredictability, its spontaneity; it is simply too dangerous, wild, and alive, too much like Nature herself. The Irish poet O'Donohue (2007) reflected that "The theologians have domesticated God, yet there is a wonderful danger to God that we have totally forgotten. ... One of our major tasks is to make God dangerous again" (42:00). In a similar vein, I think that much of psychology has been coopted by the left brain's determination to eradicate uncertainty. To this goal it has attempted to domesticate the psyche, to rid it of its wildness, yet in so doing has simultaneously fenced in its vitality, dulled its radiant beauty, dammed its emergent poetry. If we need God to be dangerous again, so too we need the psyche to be dangerous, even perilous once more, for therein lies its life force. As the German poet Rilke reminded us,

Works of art always spring from those who have faced the danger, gone to the very end of an experience, to the point beyond which no human being can go. The further one dares to go, the more decent, the more personal, the more unique a life becomes. (qtd. in Fox, 2004, p. 72)

Thus, if we are to create art out of our lives, if we are to fulfill our destinies at individual and collective levels, we must face the unfamiliar, not flee from it. Active imagination's stepping into conversation with unexplored landscapes, both inner and outer, becomes a rebellious, even revolutionary move in a society that favors predictability over spontaneity, control over creativity. 


\section{The Call of the Wild}

"One does not become enlightened by imagining figures of light, but by making the darkness conscious" (Jung, 1954/1968, pp. 265-266 [CW 13, para. 335]). For Jung, an essential component of individuation was the incorporation of the shadow, that part of the unconscious where everything disowned festers. When we deny our shadow, not only does it emerge in our complexes, but it also appears in our dreams, often in the form of nightmare figures.

I recently had just such a visitation. In the dream I was a child and there was a rat hiding in the front room of our home. While two men went in to try and kill the rat, I was handed a gun and told, should the rodent come near me, I must shoot it. To my horror, I heard a scratching under the floorboards and was shocked to glimpse the tail and haunches of the rat as it disappeared behind a box. Emerging from its hiding place, the animal began to morph into a young woman, crawling toward me on her hands and knees. She had a wild look in her eyes, her long, greasy hair dragged on the ground, and she appeared utterly desperate. In a moment of bewildered shock and fear, I raised the gun and shot her. While she crumpled, she did not die but continued to drag herself toward me.

\section{The Neurobiology of Nightmare Figures}

Interestingly, the dream mirrors an episode from my childhood when a rat really was trapped in the living room of our old terraced house. Is it possible that the nightmare figure of the rat/desperate girl represents, in part, the memory of this event that may not have been sufficiently processed? As psychotherapist Badenoch (2011) explained,

Our minds can become fragmented along different kinds of fault lines when painful or frightening experiences are not met with repairing attunement and care. These shards of experience remain separate from the flow of integrating energy and information in the brain, and because they are so disconnected from possibly mediating input, they are easily triggered by an internal or external reminder. (p. 48)

However, because our brains also have an innate drive toward integration, such dissociated neural nets will seek opportunities to escape their limbic prison through being reremembered in warmer, more compassionate environments. Reexperiencing the original memory in a safe space modifies its felt sense, softening its ragged edges as it becomes integrated into the mainstream flow of the brain (Badenoch, 2008, pp. 206-218). 
This type of knitting together of dissociated neural networks occurs during sleep and very possibly while we dream (Mason et al., 2007). Could the appearance of the rat/desperate girl in my dream life have been my sleeping brain's own attempt at neural integration? If this dream figure were to be imagined as a dissociated self state, then which aspects of me might she represent? Considering these questions brought to mind Johnson's (1986) statement that "ideas and images should enter into your emotions, your muscle fibers, the cells of your body. It takes a physical act. When it registers physically it also registers at the deepest levels of your psyche" (pp. 100-101).

\section{Living the Image}

Seeking to enter into a flesh-and-blood relationship with the mysterious visitor, I decided to embody the rat-girl during a series of authentic movement classes. As I crawled along the floor, hair kissing the ground and wild eyes burning, waves of emotion, intuitions, and insights tumbled into consciousness. Initially, she seemed to be a desperate spokeswoman for my anima or feminine side, an abandoned, emaciated figure starved of nurturance, understanding, and love. She appeared to be calling attention to those feminine aspects of myself that I had cut off, namely my deep feeling and intuitive sides, and she was crying out for help.

Over time I wondered whether, having morphed out of a rat, that most earthy of creatures, she was also speaking somehow on behalf of the planet? Could her cries have originated not only from my own feminine, animal body but also from the body of the earth that is under such a terrible assault in our modern world? According to deep ecologists, Macy and Brown (2014),

We are not closed off from the world, but are integral components of it, like cells in a larger body. When that body is traumatized, we sense that trauma, too. When it falters and sickens, we feel its pain, whether we pay attention to it or not. (p. 27)

Clinical psychologist Aizenstat (2003) suggests that the pain of the earth is indeed communicated to us through our dreams: "At the dimension of the World Unconscious, the inner subjective nature of the world's beings are experienced as dream images in the human psyche" (p. 4). Interestingly, even though I had caused the rat-girl great suffering by shooting her, she continued to drag herself toward me. This attempt at rapprochement seems to be mirrored on a global scale as Earth continues to nourish us, offering moments of deep communion, companionship, awe and wonder; all this in spite of our profound maltreatment of the planet. 


\section{From Desperation to a Wild, Grounded Strength}

Over the course of several months, as I invited the rat-girl into an embrace with the nurturing figures of my inner world, I felt her gradually calm and shift into a more regulated neurobiological state. After taking in sufficient nourishment from this warm atmosphere, she rose up once more, wild and fierce, yet also beautiful, infused with a new, grounded strength. Embodying this more powerful version of the dream figure, I began to tap into the positive aspects of her raw, spontaneous, Earth-bound vitality. No longer the bedraggled, anorexic girl, she had become a wild, untamed source of primordial energy.

Joining forces with the tiger of my childhood dreams, she is heralding a new life force within me, a power that refuses to be shackled by the past, is not afraid to break the rules, and is determined to step fully into the generative matrix. This new current inside needs the tiger's fangs and supple, rippling strength; it also requires the wild woman's ability to crawl close to the ground, to flash her dagger eyes, and to snarl her demands. It is a movement aligned with the powers of the cosmos, streams of energy that are both destructive and life-giving, finding their greatest creativity in times of chaos and upheaval.

\section{From Dictatorship to Democracy}

When I consider my journey in the authentic movement class from a neurobiological point of view, something quite surprising comes up. It was my physical embodiment of the dream image, rather than any type of rational thought process that enabled its energy and insights to emerge. My experience fits with the new picture that is emerging from neuroscience around how the human organism actually functions. Far from the old framework of the ego sitting on high, issuing dictates from the control and command center of the head, the "I think therefore I am model," according to Levine (2010), our systems actually operate from a bottom-up perspective as messages are sent from the most primitive parts of the brain to the most complex (p. 121). Literally thousands of physical sensations, feelings, and perceptions feed upwards to create our thoughts, the stories we tell ourselves, and the narratives of our lives. In fact, the ratio of communication from the gut brain to the head brain is 7-1 (p. 122). This highly democratic system gives credence to the old wisdom of "listening to your gut" or "making a gut decision." I wonder to what extent we allow our belly brains to inform us about our species' current relationship to the larger Earth community. Are we permitting the wisdom of our bodies to feed into our decisions regarding the trajectory of humanity? 
Or are we running so fast that we cannot even sense the upwellings from these nonverbal parts of ourselves?

\section{Engaging the Right-Hemisphere, Embodied Self}

The intelligence of my physical self only became available when I consciously shifted into a right-brain mode of being by engaging in meditative, imaginative movement. As McGilchrist (2012) emphasized, the right hemisphere is the center of the embodied self: "It is not a representation (as it would be if it were in the left hemisphere) ... but a living image, intimately linked to activity in the world — an essentially affective experience" (p. 66). As a living image held in the right brain, my body and its associated affects were not static but were allowed to morph and transform, ultimately shifting from a place of grief and desperation to a new sense of grounded strength and raw energy. Such transmutation was possible because the right hemisphere, unlike the left, does not create static models of the world but permits reality, both inner and outer, to be in a state of flux. In addition, the right brain processes newness. It is here that novel experience is tasted, felt, mulled over, and incorporated into the system (p. 164).

\section{Feeling the Pain of the Earth}

While there are many practices that support the activation of the right hemisphere, such as yoga, meditation, martial arts, and relational therapy, to name but a few, the discipline that guided me was active imagination. By engaging my embodied, intuitive mind, this practice bypassed my left hemisphere's defenses against feeling, enabling old affects that had been festering in my body to come into conscious awareness. The influx of new energy was unleashed only after I had allowed myself to experience deeply the grief of those wilder, feeling parts that I had repressed in order to win the love and approval of others.

Could the same principle apply on a planetary level? Just as the desperate, wild girl of my dream needed soothing and nurturance, in what ways is the greater Earth community calling out for our caring and compassion? Dare we feel the deep well of grief that may arise when we step off the hamster wheel of modern life and open our eyes, ears, and hearts to the thuds of ancient forests as they hit the parched soil below; to the cries of our ancestors, the orangutans, as their homes go up in flames; to the last suffocating gasps of sea life no longer able to withstand the toxification of our oceans?

Contemplating the enormity of this destruction can feel profoundly overwhelming. However, the alternative is that just like trauma survivors who must numb themselves to 
their bodies in an effort to contain their ever-present fear of annihilation, we will continue to dissociate ourselves from that larger body within which we live, planet Earth. If we are to have any hope of achieving wholeness as individuals and of redirecting our profoundly damaging planetary course, we must allow ourselves to feel the tremendous grief of the whole situation, for herein lies the creativity that is being demanded at a scale never before imagined in human history. If we can hold the planet's immense suffering in our hearts, we may find, as occurred with the desperate girl from my dream, that humanity becomes infused with a new source of strength, inspiration, and creativity, the very qualities that are required if we are to step into a mutually enhancing Earth-human relationship.

\section{Playing God}

Over the past 250 years, humanity has become so powerful that whether we wish to admit it or not we are literally playing God here on Earth. For the first time in this planet's history, biological evolution is now being completely overwhelmed by cultural evolution: "Our mind and hands represent a new source of 'newness,' putting at Nature's disposal a fundamentally new mechanism of evolution" (Russell, qtd. in Fox, 2004, p. 29). Yet in large part we appear to be operating as the gods of destruction. Humanity's most pressing task right now is to wrestle our creativity back from its current demonic manifestation (Fox, 2004, p. 10).

According to theologian Fox (2004), if used for wise and compassionate purposes, creativity can be our very highest calling: "Creating is our imitating of Divinity. We are here to imitate Divinity. Nothing less. . . But we do not generate alone, we generate in communion with the Divine who dwells and generates within us" (p. 72). These profound statements feel so true to me. In those moments when I sense myself to be engaging with deep streams of creativity, there is an impression of timelessness and spaciousness, a feeling of encountering the sacred.

Yet who or what is this divine force? The 14th-century Christian mystic Eckhart called God a "nameless nothingness" and a source of "pure generation" (qtd. in Fox, 2004, p. 72). Interestingly, these images of the Divine have an uncanny similarity to our current understanding of the origins of the universe. In the language of physics, quantum fluctuation refers to the manner in which elementary particles fluctuate in and out of existence. "Particles boil into existence out of sheer emptiness ... there was no fireball, then the fireball erupted . . . all that has existence erupted out of nothing" (Swimme, 
2001, p. 37). The extraordinary truth of the matter is that the universe surged out of nothingness and then set about the work of creativity in the most spectacular fashion.

So, if in Fox's (2004, p. 72) words, we are here to imitate Divinity, could our role be imagined as one of embodying this empty realm, becoming the space through which creativity can pour into existence? The processes of clearing the mind and relaxing the ego prior to engaging in active imagination seem to be oriented toward achieving just such a state of emptiness. Thus, through active imagination, are we not setting the stage for our imitation of Divinity, clearing the way for our union with the Divine? By creating a space of pure potentiality, could it even be said that we are imitating the birth of the universe? Does not the quivering realm of no-thing-ness from which the flamboyant forms of our imagination burst forth bear a striking resemblance to the void out of which the first protons boiled into existence? For me, the answer to all three questions is a resounding yes. It appears that our dialoguing with the imagination is tantamount to both merging with the Divine and joining with the very emergence of the universe itself. If we are, as Swimme (2007) argued, the universe birthing itself in this very moment, then does it not behoove us to model our creating on that first grand act of creation, the flaring forth of the original fireball out of the primordial void? (57:00).

In my view, engaging with our imagination in the manner of the Big Bang, through a process of emptying, letting go, and allowing an upsurging from the nothingness of our being, is the pathway to wrestling our creativity back from its current demonic manifestations. When we ignite our imaginative faculties in such a primeval way the world shows up as animated, interconnected, and even divine; a perspective that bears an uncanny resemblance to Jung's (1963) experience of the Self:

At times I feel as if I am spread out over the landscape and inside things, and am myself living in every tree, in the plashing of the waves, in the clouds and the animals that come and go, in the procession of the seasons. (pp. 225-226)

\section{A Holistic Lens}

Living from such intimacy with the greater Earth community appears to be an absolute prerequisite to our individuation at the planetary level, to our global transition to a life-sustaining society. Through developing holistic, right-hemisphere modes of perception, we begin to see through the Western myth that we are a collection of separate selves, encased in isolated brains, wandering about in discrete bodies, in competition with one another, and at war with the other species and the planet. Instead, we perceive the reality that we are neither separate from nor superior to nature; rather, not only are 
we a part of nature, we are nature. As we sense our oneness with all that is we may glimpse the unus mundus, Jung's (1976) concept of the world as a single inseparable whole: "The multiplicity of the empirical world rests on an underlying unity. . . . Everything divided and different belongs to one and the same world" (p. 538). From this standpoint, what we do to the natural world, we do to ourselves. We are simply another bud on a branch of the tree that is this Earth, and as we devastate the biosphere without, so too we maul the psyche within. Conversely, by taking steps to reclaim the soils of the earth, we begin to reconstitute the ground of our being; as we learn to cherish the forests without, so too we nourish the tender shoots within; and as we undam the mighty rivers, we unleash the psychic vitality we so desperately seek.

However, for all its wonderful capacities, the right brain cannot go it alone. What is called for is integration, with the powerful left hemisphere operating in service of the wisdom of the right (McGilchrist, 2012, pp. 428-460). As the side capable of manipulation, it is the left that can take the holistic vision of the right and break it down, allowing for its practical execution out there in the world. Yet what vision are we executing? What is our purpose here on the planet?

\section{Our Role as Human Beings}

Humans are in a unique position since, to a large extent, our purpose is not encoded in our genes as is the case with other animals. While everything else in the universe has its own task to perform, from the phytoplankton of the oceans providing the oxygen we breathe, to the bees pollinating flowering plants worldwide, only human beings have to create their sense of purpose. This calling takes a particular form in each individual, but Swimme (2001) argued that as the self-reflexive awareness of the cosmos, our species has one overarching role:

The human provides the space in which the universe feels its stupendous beauty.

... Think of what it would be like if there were no humans on the planet: the mountains and the primeval fireball would be magnificent, but the earth would not feel any of this. Can you see the sadness of such a state? The incompleteness? Humans can house the tremendous beauty of Earth, of life, of the universe. We can value it, feel its grandeur. (pp. 3233)

Gifted with an unprecedented capacity for awe and wonder could it be that we are here to appreciate the magnificence of all creation, to stand awestruck beneath a blanket of shimmering stars, to have our breath taken away by a flock of wild geese soaring in 
symmetry? Yet we can only perform this role of holding the splendor of the universe if we are capable of developing awe, if we are able to drop our "sleek certainties" (Heschel, 1976, p. 58):

To a mind unwarped by intellectual habit, unbiased by what it already knows; to unmitigated innate surprise there are no axioms, dogmas; there is only wonder. The realization is that the world is too incredible, too meaningful for us. The existence of the world is the most unlikely, the most unbelievable fact. . . . Who could believe it, who could conceive it? (p. 58)

This awestruck perspective depends upon our being present and embodied enough to see life afresh, as though for the very first time, in each moment. It requires that we periodically step out of the left hemisphere, which delivers only representations of the world, and into the right side, which is directly in touch with here-and-now felt experience (McGilchrist, 2012, p. 70). It necessitates engaging our imaginative faculties, for it requires a leap of the imagination truly to see ourselves as the direct descendants of the stars above, as the atoms and energy from the beginning of time, here right now thinking, feeling, and creating (Swimme, 2007, 56:30).

\section{Therapeutic Implications}

At this moment in time, I sense that we are being called to stand in wonder not only in the face of the miracles of the universe but also in the presence of one another. For those of us who work as psychotherapists, psychologists, or healers of any kind, what would it be like to perceive our clients through a cosmological lens? Could we see the person before us as not only an individual, not simply part of a family, community, or culture, but also as 13.8 billion years of "creativity in the form of one particular human body" (Swimme, 2002, p. 13)? Standing in this space, I feel the only appropriate response is one of sheer awe and reverence.

How would it affect the dance with our clients to hear their hopes and dreams both as manifestations of their own innate desires and as expressions of the fundamental alluring activity of the universe? This allurement permeates the macrocosm on all levels of being, attracting Earth to the sun, holding the Milky Way together, and preventing our planet from dissolving into a huge dark cloud (Swimme, 2001, p. 48). By supporting our clients to pursue their deepest allurements, not only are their individual lives impacted, but on a cosmic level "we help bind the universe together. The unity of the world rests on the pursuit of passion" (p. 48). 
What would it be like to imagine that the therapeutic process itself is directly involved in binding together the vast emergent cosmos? The idea that our work may support the integration of our clients' brains while also facilitating the very cohesion of the universe, in Hillman and Ventura's (1992) words, takes the top off my head (p. 69).

By revisioning psychotherapy in this way we might infuse the endeavor with a new source of energy, bringing profound purpose and meaning in those moments when we feel lost in the woods of an individual's life. It could fortify us against the inevitable burnout involved in conceiving of our vocation in too limited and superficial a manner.

\section{Summary and Conclusions}

As the 13th-century Sufi mystic Jalal ad-Din Muhammad Rumi wrote, "We come spinning out of nothingness, scattering stars like dust[;] the stars form a circle . . . and in the center we dance" (qtd. in Liebert, 1981, p. 13). The idea, celebrated by poets and sages throughout history, that everything emerges from emptiness is now being confirmed by modern science with the discovery that elementary particles do just thatthey literally leap out of the nothingness (Swimme, 2001, p. 36). Through the process of active imagination, we allow images to spring out of that very same void, giving them space to grow, share their wisdom, and work their magic in the broken, desolate corners of our psyches. Imaginal flows don't simply heal in this interior way, but their blessing also extends outwards as they reengage us with the sacred dimension of our fellow human beings, the greater Earth community, and the planet itself.

By engaging the holistic lens of the right brain we open the portal to glimpsing ourselves in our planetary context. As ideas of inside and out, I and other, my body and Earth's terrain dissolve in the sea of the imaginative right cortical hemisphere, our sense of physical and temporal separation evaporates. In an instant, our union with everything that exists through our common origin in the primeval fireball rushes into consciousness. From this unitary perspective it becomes nearly impossible for us to view the hardwood forest or leaping salmon as simply resources for our consumption. Instead, they become extensions of ourselves for they, like us, are exquisite manifestations of the boundless creativity of the cosmos.

From the epicenter of the imagination emerges the shockwave of realization that just as the mighty Himalayas are Earth in the form of a mountain range, and the giant redwoods are Earth in the form of a forest, we are Earth in human form. In essence, we are the planet becoming aware of itself, developing the capacity to reflect upon its own glorious origins and create new visions for its future. Thus, as we engage with the 
primordial flows of creativity that pulse through our beings, recognizing them and giving them shape, we simultaneously facilitate the planet's individuation, allowing Earth to express itself in forms never before seen, heard, felt or touched in its 4.6 billion-year history.

Due to the omnipresent influence of the human, as we individuate on a species level we impact the future of the entire planet. For example, as we get in touch with deep currents of compassion within ourselves, then compassion begins to be woven into the very evolutionary dynamics of life in an entirely new way (Swimme, 1997, 201:00). The type of vibrant, mutually enhancing Earth community that lies on the other side of such a macrophase transition is beyond our wildest imaginings. This is an awesome destiny, but it will only be realized if we are willing to embody all of who we are, bringing back online the empathetic, holistic, imaginal circuitry of the right hemisphere, thereby embracing our potential as the very heart and mind of the planet itself.

\section{Works Cited}

Aizenstat, S. (2003). Nature dreaming: Depth psychology and ecology. Unpublished article. Retrieved from http://www.dreamtending.com/naturedreaming.pdf

Badenoch, B. (2008). Being a brain-wise therapist: A practical guide to interpersonal neurobiology. New York, NY: W. W. Norton.

Badenoch, B. (2011). The brain-savvy therapist's workbook. New York, NY: W. W. Norton.

Berry, T. (1988). Dream of the earth. New York, NY: Random House.

Berry, T. (1999). The great work: Our way into the future. New York, NY: Bell Tower.

Campbell, J. (with Moyers, B.) (1988). The power of myth (B. S. Flowers, Ed.). New York, NY: Doubleday.

Chodorow, J. (1997). Introduction. In J. Chodorow (Ed.), Jung on active imagination (pp. 1-20). Princeton, NJ: Princeton University Press.

Fox, M. (2004). Creativity: Where the divine and human meet. New York, NY: TarcherPerigee.

Heschel, A. J. (1976). Man is not alone: A philosophy of religion. New York, NY: Farrar, Straus \& Giroux.

Hillman, J. (1997). Dream Animals. San Francisco, CA: Chronicle Books.

Hillman, J., \& Ventura, M. (1992). We've had a hundred years of psychotherapy and the world's getting worse. New York, NY: Harper Collins.

Johnson, R. A. (1986). Inner work: Using dreams and active imagination for personal growth. New York, NY: Harper \& Row. 
Jung, C. G. (1960). On the nature of the psyche (R. F. C. Hull, Trans.). In H. Read et al. (Series Eds.), The collected works of C. G. Jung (Vol. 8, $2^{\text {nd }}$ ed., pp. 168-170).

Princeton, NJ: Princeton University Press. (Original work published 1946)

Jung, C. G. (1963). Memories, dreams, reflections (A. Jaffé, Ed., R. Winston \& C. Winston, Trans.). New York, NY: Vintage. (Original work published 1961)

Jung, C. G. (1968). The philosophical tree (R. F. C. Hull, Trans.). In H. Read et al. (Series Eds.), The collected works of C. G. Jung (Vol. 13, pp. 253-271). Princeton, NJ: Princeton University Press. (Original work published 1954)

Jung, C. G. (1969a). The psychology of the child archetype (R. F. C. Hull, Trans.). In H. Read et al. (Series Eds.), The collected works of C. G. Jung (Vol. 9i, 2nd ed.,

pp. 151-181). Princeton, NJ: Princeton University Press. (Original work published 1940)

Jung, C. G. (1969b). Yoga and the West (R. F. C. Hull, Trans.). In H. Read et al. (Series Eds.), The collected works of C. G. Jung (Vol. 11, 2nd ed., pp. 529-537). Princeton, NJ: Princeton University Press. (Original work published 1936)

Jung, C. G. (1976). The conjunction (R. F. C. Hull, Trans.). In H. Read et al. (Series Eds.), The collected works of C. G. Jung (Vol. 14, 3rd ed., pp. 533-544). Princeton, NJ: Princeton University Press. (Original work published 1963)

Jung, C. G. (1997). Visions: Notes of the seminar given in 1930-1934 by C. G. Jung

(Vol. 1) (C. Douglas, Ed.). Princeton, NJ: Princeton University Press.

Levine, P. A. (1997). Waking the tiger: Healing trauma. Berkeley, CA: North Atlantic Books.

Levine, P. A. (2010). In an unspoken voice: How the body releases trauma and restores goodness. Berkeley, CA: North Atlantic Books.

Liebert, D. (1981). Rumi: Fragments, ecstasies. New Lebanon, NY: Omega.

Macy, J., \& Brown, M. J. (2014). Coming back to life: Practices to reconnect our lives, our world. Gabriola Island, British Columbia, Canada: New Society.

Marks-Tarlow, T. (2012). Clinical intuition in psychotherapy: The neurobiology of embodied response. New York, NY: W. W. Norton.

Mason, M., Norton, M., Van Horn, J., Wenger, D., Grafton, S., \& Macrae, N. (2007). Wandering minds: The default network and stimulus-independent thought. Science, 315, 393-395.

McGilchrist, I. (2011). The divided brain [Video file]. New York, NY: TED. Retrieved from https://www.ted.com/talks/iain_mcgilchrist_the_divided_brain

McGilchrist, I. (2012). The master and his emissary: The divided brain and the making of the modern world. New Haven, CT: Yale University Press.

O’Donohue, J. (2007). Imagination as the path of spirit [MP3]. London, England: Greenbelt. Retrieved from https://www.greenbelt.org.uk/media/talks/14229-john-odonohue/

O’Donohue, J. (2015). The inner landscape of beauty [MP3]. Minneapolis, MN: On Being.

Rowland, S. (2012). The ecocritical psyche: Literature, evolutionary complexity and Jung. New York, NY: Routledge. 
Vol. 12, No. 1, 2017

Shulman, H. (1997). Living at the edge of chaos: Complex systems in culture and psyche. Einsiedeln, Switzerland: Daimon.

Stein, M. (2013). Jung's map of the soul: An introduction. Peru, IL: Open Court.

Swimme, B. (1997). The earth's imagination. [Film]. Center for the Study of the Universe. Retrieved from https://storyoftheuniverse.org/store-2/dvd/the-earths-imagination/

Swimme, B. (2001). The universe is a green dragon: A cosmic creation story. Rochester, VT: Bear and Company.

Swimme, B. (2002, June). Where does your faith fit in the cosmos? US Catholic, 67(6), 8-16. Retrieved from http://thegreatstory.org/SwimmeUSC.pdf

Swimme, B. (2007). Being present [Film]. Global Mindshift Foundation. Retrieved from https://www.youtube.com/watch?v=TRykk_0ovI0\&list=PLEAE66D74118D75D5

Swimme, B. (2011, September). Journey of the universe [Video file]. Lecture presented at Dominican University of California. Retrieved from https://www.youtube.com/ watch? $=2$ w9Ai48zxnk

Swimme, B., \& Berry, T. (1992). The universe story: From the primordial flaring forth to the ecozoic era-A celebration of the unfolding of the cosmos. New York, NY: HarperCollins.

Teilhard de Chardin, P. (1955). The Phenomenon of Man. Toronto, Ontario, Canada: The Great Library Collection.

Watts, A. (1989). The book: On the taboo against knowing who you are. New York, NY: Random House. 